\title{
IN VITRO CELL CULTURE DRUG RESISTANCE TESTING
}

*Prabhavathy Munagala

\section{Introduction}

Drug development and screening programme for the identification of a novel cancer chemotherapeutic agent involves extensive preclinical evaluation of vast number of chemicals for detection of their antineoplastic activity. The safety of drugs necessitates the screening strategies (Freshney, 1992).

The development of drug resistance is a major obstacle to effectiveness of chemotherapeutic treatment of human fumors with cytotoxic agents. Drug resistance is described as a multifactor phenomenon, involving the expression of defense factors and/or detoxification mechanisms, alterations in drug target interactions and cellular response to specific cytotoxic lesions (DNA damage). Although the proposed mechanisms may contribute to the development of a variable degree of cellular resistance, it is possible that the cell response, DNA repair/apoptosis, following DNA damage plays a critical role in determining cellular chemosensitivity (Zunino et al., 1997).

Anticancer drugs either cytotoxic or cytostatic are either synthetic or naturally extracted products. These drugs reduce the tumor cell population either by killing or inhibiting the growth of susceptible cells. Most of the anticancer drugs are cytotoxic in current

* Dept. of Biotechnology, Ayya Nadar Jonaki Ammal College, Sivakasi- 626 124. Tamilnadu. 
use and have shown to induce apoptosis in susceptible cells. The fact that disparate agents, which interact different targets, include cell death with some common features viz., endonucleolytic cleavage of DNA and changes in chromatin condensation suggests that cytotoxicity is determined by the ability of the cell to engage this so called "programmed" cell death (Hickman, 1992).

Thus, with the view of exploiting the potential link between apoptosis and malignant cell growth, the present investigation has been designed to screen upto six compounds for potential anticancer activity. The operation of the present screening strategies utilizes four different cancerous cell lines to a novel compound GH in different forms with slight modification in its molecular weight, at five different concentrations ranging from $100 \mathrm{mM}$ to $0.01 \mathrm{MM}$ with 10 fold dilutions under in vitro conditions.

Thus, the present investigation includes approximately 120 direct comparisons to find out the $50 \%$ growth inhibition values in different cancerous cell lines like Prostrate, Ovary, Hepatic and Breast.

\section{Materials and Methods}

\section{Cell Lines and Drugs}

Four human tumor cell lines representing breast, hepatic, prostate and ovary and 6 drugs representing $\mathrm{GH} 1, \mathrm{GH} 2, \mathrm{GH} 3, \mathrm{GH} 4, \mathrm{GH} 5$ and $\mathrm{GH} 6$ were exploited in the present investigation.

\section{Formulae to Calculate Volume of DMSO}

Keeping the weight of drug constant ( $5 \mathrm{mg}$ ), a formula was used to calculate the volume of DMSO required to dissolve the drug to prepare $200 x$ stock solution (Table 1).

$$
\text { Volume of the Drug in } \mu \mathrm{l}=\frac{\text { Weight of the drug in } \mathrm{mg}}{\text { Molecular weight of the drug }} \times \cdot 50,000
$$


Table 1. Preperation of stock solution

\begin{tabular}{|c|c|c|c|}
\hline S.No & Drug & Molecular weight & $\begin{array}{c}\text { Volume of } \\
\text { DMSO }(\mu \mathrm{l})\end{array}$ \\
\hline 1 & GH1 & 380 & 658 \\
2 & GH2 & 393 & 638 \\
3 & GH3 & 389 & 626 \\
4 & GH4 & 390 & 641 \\
5 & GH5 & 419 & 597 \\
6 & GH6 & 423 & 596 \\
\hline
\end{tabular}

\section{Selection of Flasks for Plating}

Flasks with $70 \%-80 \%$ confluency were selected and checked for their contamination and cell morphology under Inverted phase contrast microscopy.

\section{Preparation of Cells for Flating}

The cell monolayer was rinsed with PBS to remove the traces of serum. The layers were then tyrpsinized to dislodge the cells followed by resuspension in $8 \mathrm{ml}$ basal medium containing serum to stop the action of trypsin and transferred to $15 \mathrm{ml}$ centrifuge tube.

\section{Sulphorhodamine Bassay}

$100 \mathrm{ml}$ of cells of cell density $1 \times 10^{4}$ was inoculated into 96 well microtitre plate using multichannel pipette leaving the first and last rows and columns to facilitate negative control $(\mathrm{NC})$ where only $100 \mathrm{ml}$ of complete medium alone was added to check out the contamination. Soon after the plating, the cells were incubated in $\mathrm{CO}_{2}$ incubator at $37^{\circ} \mathrm{C}$ and $5 \% \mathrm{CO}_{2}$ for 24 hours prior to the drug addition so as to facilitate the cell proliferation (Skehan, 1989; Fricker, 1990).

After 24 hours a part of each cell line was fixed in situ with $25 \mathrm{ml}$ of $50 \%$ TCA (10\% final concentration) to represent a measurement of the cell density for each cell line at the time of drug addition $(\mathrm{Tz})$.

A part of each cell line was added with additional fresh $100 \mathrm{ml}$ complete medium to represent the total growth of cell population i.e. positive control (c). 


\section{Drug Addition}

At the time of drug addition (Table 3$)$ an aliquot of $200 \times(20 \mathrm{mM})$ drug concentrate frozen at $-70^{\circ} \mathrm{C}$ was thawed, sterile filtered using $0.22 \mathrm{~m}$ membrane filter (Acrodisc) and diluted twice $(200 \mathrm{mM})$ to obtain the desired final maximum test concentration $(100 \mathrm{mM})$ with complete medium. Additional four, 10 fold serial dilutions were prepared to provide a total of five drug concentrations (Table 2) representing $200 \mathrm{mM}$, $20 \mathrm{mM}, 2 \mathrm{mM}, 0.2 \mathrm{mM}$ and $0.02 \mathrm{mM}$ respectively. Further, $100 \mathrm{ml}$ of each concentrate was added in the 96 well microtitre plate. Following drug addition, the plates were incubated for additional 48 hours at $37^{\circ} \mathrm{C}$ and $5 \% \mathrm{CO}_{2}$ to facilitate the interaction between drugs and cells.

Table 2: Preparation of Drug dilutions.

\begin{tabular}{|c|c|c|c|c|c|}
\hline Concentration & $200 \mu \mathrm{M}$ & $20 \mu \mathrm{M}$ & $2.0 \mu \mathrm{M}$ & $0.2 \mu \mathrm{M}$ & $0.02 \mu \mathrm{M}$ \\
\hline $\begin{array}{l}\text { Volume of } \\
\text { Drug added }\end{array}$ & $\begin{array}{l}10 \mu \mathrm{l} \text { of } \\
20 \mathrm{mM} \\
\text { Drug } \\
\text { solution }\end{array}$ & $\begin{array}{l}100 \mu 1 \text { of } \\
200 \mu \mathrm{M} \\
\text { Drug } \\
\text { solution }\end{array}$ & $\begin{array}{l}100 \mu \mathrm{l} \text { of } \\
20 \mu \mathrm{M} \\
\text { Drug } \\
\text { solution }\end{array}$ & $\begin{array}{l}100 \mu \mathrm{l} \text { of } \\
2.0 \mu \mathrm{M} \\
\text { Drug } \\
\text { solution }\end{array}$ & \begin{tabular}{|l}
$100 \mu \mathrm{l}$ of \\
$0.2 \mu \mathrm{M}$ \\
Drug \\
solution \\
\end{tabular} \\
\hline $\begin{array}{l}\text { Volume of } \\
\text { complete } \\
\text { medium }\end{array}$ & $990 \mu 1$ & $900 \mu 1$ & $900 \mu 1$ & $900 \mu 1$ & $900 \mu 1$ \\
\hline
\end{tabular}

Table 3: Addition of drug dilutions to the assay plate

$\begin{array}{lllll}100 & 10 & 1.0 & 0.1 & 0.01\end{array}$

\begin{tabular}{|l|l|l|l|l|l|l|l|l|l|l|l|}
\hline NC & NC & NC & NC & NC & NC & NC & NC & NC & NC & NC & NC \\
\hline NC & GH1 & GH1 & GH1 & GH1 & GH1 & GH1 & $\mathrm{Tz}$ & $\mathrm{Tz}$ & $\mathrm{Tz}$ & $\mathrm{Tz}$ & $\mathrm{NC}$ \\
\hline $\mathrm{NC}$ & $\mathrm{GH} 2$ & $\mathrm{GH} 2$ & $\mathrm{GH} 2$ & $\mathrm{GH} 2$ & $\mathrm{GH} 2$ & $\mathrm{GH} 2$ & $\mathrm{Tz}$ & $\mathrm{Tz}$ & $\mathrm{Tz}$ & $\mathrm{Tz}$ & $\mathrm{NC}$ \\
\hline $\mathrm{NC}$ & $\mathrm{GH} 3$ & $\mathrm{GH} 3$ & $\mathrm{GH} 3$ & $\mathrm{GH} 3$ & $\mathrm{GH} 3$ & $\mathrm{GH} 3$ & $\mathrm{Tz}$ & $\mathrm{Tz}$ & $\mathrm{Tz}$ & $\mathrm{Tz}$ & $\mathrm{NC}$ \\
\hline $\mathrm{NC}$ & $\mathrm{GH} 4$ & $\mathrm{GH} 4$ & $\mathrm{GH} 4$ & $\mathrm{GH} 4$ & $\mathrm{GH} 4$ & $\mathrm{GH} 4$ & $\mathrm{C}$ & $\mathrm{C}$ & $\mathrm{C}$ & $\mathrm{C}$ & $\mathrm{NC}$ \\
\hline $\mathrm{NC}$ & $\mathrm{GH} 5$ & $\mathrm{GH} 5$ & $\mathrm{GH} 5$ & $\mathrm{GH} 5$ & $\mathrm{GH} 5$ & $\mathrm{GH} 5$ & $\mathrm{C}$ & $\mathrm{C}$ & $\mathrm{C}$ & $\mathrm{C}$ & $\mathrm{NC}$ \\
\hline $\mathrm{NC}$ & $\mathrm{GH} 6$ & $\mathrm{GH} 6$ & $\mathrm{GH} 6$ & $\mathrm{GH} 6$ & $\mathrm{GH} 6$ & $\mathrm{GH} 6$ & $\mathrm{C}$ & $\mathrm{C}$ & $\mathrm{C}$ & $\mathrm{C}$ & $\mathrm{NC}$ \\
\hline $\mathrm{NC}$ & $\mathrm{NC}$ & $\mathrm{NC}$ & $\mathrm{NC}$ & $\mathrm{NC}$ & $\mathrm{NC}$ & $\mathrm{NC}$ & $\mathrm{NC}$ & $\mathrm{NC}$ & $\mathrm{NC}$ & $\mathrm{NC}$ & $\mathrm{NC}$ \\
\hline
\end{tabular}




\section{Termination and Processing of Plates}

After 48 hours of incubation, in the case of adherent cells, the assay was terminated by the addition of $50 \mathrm{ml}$ of $50 \%$ cold TCA (10\% final concentration) so as to facilitate the precipitation of protein and prevent further proliferation and incubated at $4^{\circ} \mathrm{C}$ for 60 minutes.

Following incubation, the supernatant was discarded to remove the unfixed dead cells and the plates were washed five times with tap water and air-dried.

$100 \mathrm{ml}$ of $0.4 \%$ sulphorhodamine B prepared in $0.1 \%$ acetic acid was added to stain the bounded protein. After staining unbounded dye was removed by washing five times with $0.1 \%$ acetic acid and the plates were air-dried. Protein bound stain was subsequently, solubilised with $100 \mathrm{ml} \mathrm{of} 10 \mathrm{mM}$

Tris buffer. The absorbance of total protein left stained in the plates was read on an automated plate reader at $492 \mathrm{~nm}$.

\section{Analysis of Percentage Growth}

The percentage growth was calculated using software at each of drug concentration exploiting the absorbance measurements at Time zero, (Tz), 72 hours (Positive Control) and 48 hours (Test growth Inhibition) in presence of drug at five different concentrations where $48 \mathrm{~h}$ seemed to be growth inhibition period.

The dose response parameters viz., $\mathrm{Ti}, \mathrm{Tz}$ and $\mathrm{C}^{\prime}$ were assayed for percentage growth by adopting the formulae, $[(\mathrm{Ti}-\mathrm{Tz}) /(\mathrm{C}-\mathrm{Tz})] \times 100=50$ and $[(\mathrm{Ti}-\mathrm{Tz})$ $/ T z] \times 100=.50$.

Further, the drug concentration was plotted on $X$-axis and the percentage growth on $Y$-axis with a scale of -100 to 100 with ticks at 50 . The interpolation of 50 on $Y$ axis gave a concentration of $50 \%$ growth inhibition value (GI 50 value). Based on the $\mathrm{Gl} 50$ values obtained from the graphical representation, the drug could be considered as either sensitive or resistant or intermediate.

\section{Results}

After plating, on observation under Inverted phase contrast Microscope, no cells were found in negative control (NC) wells, and the round cells were found in other 
Table 4: $\mathrm{Gl} 50$ values of Drugs $\mathrm{GH} 1$ to $\mathrm{GH} 6$ in various human cancerous cell lines

\begin{tabular}{|l|l|l|l|l|l|}
\hline Drug & Prostate & Ovary & Hepatic & Breast & Interpretation \\
\hline GH1 & 0.25 & 0.3 & .03 & 0.1 & Sensitive \\
\hline GH2 & 30 & 35.0 & 30.0 & 30.5 & Intermediate \\
\hline GH3 & 1.5 & 9.0 & .07 & 0.7 & Sensitive \\
\hline GH4 & $>100.0$ & $>100.0$ & $>100.0$ & $>100.0$ & Resistant \\
\hline GH5 & .08 & 1.0 & 0.7 & 2.0 & Sensitive \\
\hline GH6 & 30.0 & 20.0 & 40.0 & 50.0 & Resistant \\
\hline
\end{tabular}

Adition of $50 \%$ TCA brought turbidity and color change in the medium and the precipitated protein of cells appeared as floccules.

On termination, 50\% cold TCA precipitated the protein of adherent cell lines and $80 \%$ cold TCA first firmly fixed and then precipitated the protein of suspension cell lines.

On washing with $0.1 \%$ acetic acid, the unbound dye was removed from the wells. A clear gradation of colour intensity was observed in test wells, where the intensity of colour increased from low concentration $(0.01 \mathrm{mM})$ to high concentration $(100 \mathrm{mM})$ of drug. The intensity of colour in control wells was maximum and nill in negative control wells.

Sulphorhodamine B assay of 6 anti cancer drugs against cancerous cell lines revealed that, the cell lines are sensitive to drugs $\mathrm{GH} 1, \mathrm{GH} 3$ and $\mathrm{GH} 5$, resistant to $\mathrm{GH} 4$ and $\mathrm{GH} 6$, intermediate to $\mathrm{GH} 2$. (Table 4)

\section{Discussion}

Chemosensitivity assays under in vitro have a number of possible applications in the development of tumor chemotherapy. Among these are the determination and identification of new agents with clinical activity in particular fumor types. This assay, especially when set up in the microtitre format, has the potential to screen large number of drugs using relatively small tumor samples (Bird et al., 1986 b). 
Although, the majority of cells grew as monolayers, the hepatic cancer cell line and lung cancer cell lines have grown as floating aggregates as shown by Carmichael (1987).

The cell culture technique, which involves a number of variables, can make it difficult to determine the cause of problems. Narrowing a problem down to the one material or one critical procedure can be a daunting task. However, problems usually can be identified by a close monitoring of the symptoms and meticulous retracting of each step in the culture process (Mather and Roberts, 1998).

Most cells are sensitive to the $\mathrm{pH}$ of their surroundings. Conditions with either too acidic or too basic result in poor cell growth and permanent cell damage: Since, the optimum pH for the most mammalian cells remain $7.2 \pm 0.2$ (Giard, 1987), present investigation have also maintained same.

After the addition of drug GH1-GH6 to wells of microtitre plates loaded with all the ten types of cancerous cell lines, of the present investigation have been read for the change in the colour intensity, followed by the determination of percentage growth and GI 50 values; which reveals that cancerous cell lines are sensitive to all the drugs.

Thus, the successful development of in vitro assay for anti cancer drug screening precipitates interest in the development of cancer therapy to suit the individual tumor and patient (Freshney, 1992). Besides, the novel drugs evolved, can also be screened for their chemosensitivity of various cancer cell types more rapidly. 